\title{
Esophageal Neurofibroma
}

National Cancer Institute

\section{Source}

National Cancer Institute. Esophageal Neurofibroma. NCI Thesaurus. Code C5704.

A non-metastasizing encapsulated neoplasm arising from nerves in the esophagus.

Morphologically, it is characterized by the presence of fibroblasts and Schwann cells. 